\title{
EFFECT OF INFORMATION SERVICES USING THE MEDIA FILM TO SELF-CONFIDENCE STUDENT OF CLASS VIII SMP NEGERI 8 METRO
}

\author{
MUDAIM \&BELARDO FARJANTOKY
}

Program Studi Bimbingan dan Konseling UM Metro

\begin{abstract}
Pessimism and attitudes that consider themselves weak and does not have the ability when facing a problem will make individual impediment in the task of development. Problems confidence that underlies the research are: a) Students are less confident in the ability it has, b) Students feel pessimistic when faced with an issue, c) Student perception subjectively, d) Students still do not do the work independently, and e) negative minded students with a state-owned. The problems of this study are whether there is an influence of information services using the medium of film to the confidence of eighth-grade students of SMP Negeri 8 Metro. The purpose of this study was to determine whether there is an influence of information services using the medium of film to the self-confidence of students in class VIII SMP Negeri 8 Metro. Subject participant is graders VIII-E total 30 students. Data were collected by questionnaire self-confidence and analyzed the data used is the t-test. The results of this study, shown by the difference in change scores of confidence from the pre-test and post-test of 17.1. Testing the hypothesis obtained calculation results thitung6,036> table $=$ 1.699. The conclusion is that the information services implemented using the film medium can be a positive influence on self-esteem, especially students of class VIII. The advice given is to use the medium of film should be done intensively and more creative by BK teachers in giving information service.
\end{abstract}

Keyword: Confidence, Service Information, Media Film. 


\section{PENDAHULUAN}

Keberhasilan siswa dalam belajar dan kehidupannya tidak hanya ditentukan oleh kecerdasan otaknya saja. Kematangan emosi, keterampilan, sosial, kepercayaan diri, dan kesantunan berperilaku merupakan faktor yang sangat menentukan dalam keberhasilan siswa. Dengan demikian pembinaan terhadap seseorang tentunya tidak hanya ditekankan pada pengembangan kemampuan berfikir saja, tetapi kecerdasan emosi, percayaan diri, keterampilan social dan kesantunan perilaku harus mendapatkan porsi yang tepat. Salah satu masalah atau hambatan yang sering dihadapi siswa dalam belajar adalah kurangnya kepercayaan diri. Rasa percaya diri merupakan suatu kekuatan atau dorongan yang ada dalam diri individu untuk melakukan suatu hal yang berpengaruh bagi kemajuan dan dalam memperbaiki diri. Percaya diri adalah suatu aspek kepribadian yang ada dalam kehidupan manusia dan sangat berpengaruh penting dalam kehidupan yang mereka lakukan. Santrock (2003) "percaya diri adalah dimensi evaluatif yang menyeluruh dari diri atau gambaran diri". Menurut Lauster (http://www.masbow.com) orang yang memiliki percaya diri yang positif adalah:

a. Keyakinan akan kemampuan diri

b. Optimis

c. Obyektif

d. Bertanggung jawab

e. Rasional dan realistis

Rasa kepercayaan diri hendaknya selalu tertanam pada individu walaupun sedang dihadapkan dengan berbagai macam masalah. Percaya diri sangat menunjang keberhasilan belajar dan kehidupannya, dengan demikian para siswa harus bisa membangun rasa percaya diri.

Kenyataan yang terjadi pada saat ini, setelah dilakukan wawancara kepada guru Bimbingan dan Konseling di SMP Negeri 8 Metro di dalam proses pembelajaran tidak selalu sesuai seperti yang diharapkan. Masih terdapat siswa yang kurang memiliki kepercayaan diri. Kurang percaya diri siswa dapat terlihat ketika belajar di kelas. Selain itu juga dari hasil pra survey dilakukan di kelas VIII, ditemukan berbagai 
masalah kurangnya kepercayaan diri siswa antara lain:

1. Siswa kurang percaya akan kemampuan yang dimilikinya

2. Siswa merasa pesimis ketika menghadapi suatu persoalan

3. Siswa perpandangan subyektif

4. Siswa masih ada yang tidak mengerjakan tugas secara mandiri

5. Siswa berfikiran negatif dengan keadaan yang dimilikinya

Perilaku yang ditunjukkan oleh peserta didik di atas mengindikaskan bahwa ada permasalahan yang dialami oleh peserta didik terkait aspek kepercayaan diri.

Kondisi tersebut jika tidak mendapat perhatian yang serius akan mengakibatkan peserta didik terjebak dalam suatu permasalsahan yang lebih komplek, sehingga berakibat buruk terhadap hasil belajar dan juga kesuksesan dimasa depan. Salah satu faktor yang diduga menjadi penyebab kurang percaya diri adalah penggunaan strategi dan kurangnya informasi bagi siswa tentang manfaat percaya diri. Rasa percaya diri yang rendah perlu diberikan layanaan tentang percaya diri dengan harapan, setelah diberikan layanan informasi bisa meningkatkan rasa percaya diri siswa.

Zainal (2012) menjelaskan bahwa, "layanan informasi, yaitu layanan bimbingan dan konseling yang memungkinkan peserta didik menerima dan memahami berbagai informasi yang dapat dipergunakan sebagai bahan pertimbangan keputusan untuk kepentingan peserta didik". Melalui layanan informasi siswa juga akan menambah wawasan dan pengetahuan yang berguna memenuhi kekurangan yang siswa miliki. Seperti halnya yang dijelaskan oleh Prayitno (2004) bahwa:

Layanan informasi merupakan suatu usaha untuk memenuhi kekurangan individu akan informasi yang mereka perlukan. Dalam layanan ini, kepada peserta layanan disampaikan berbagai informasi; dan diolah dan digunanakan individu untuk kepentingan hidup dan perkembangannya. Layanan informasi diselenggarakan oleh konselor dan diikuti oleh seseorang atau lebih peserta.

Sedangkan Menurut Tohirin (2009) "Layanan informasi bermakna usaha-usaha membekali siswa dengan 
pengetahuan serta pemahaman tentang lingkungan hidupnya dan tentang proses perkembangan anak muda". Diperlukannya informasi bagi siswa semakin penting mengingat sebagai acuan bersikap dan bertingkah laku sehari-hari, sebagai pertimbangan bagi arahan pengembangan diri, dan sebagai dasar penganbilan keputusan.

Dengan demikian, pemberian layanan informasi dengan materi yang sangat dibituhkan oleh peserta didik akan sangat membantu peserta didik memiliki rujukan dan referensi yang jelas untuk meningkatkan rasa percaya diri, baik dalam bersosialisasi dan juga dalam proses belajar. Layanan informasi merupakan layanan yang bertujuan memberikan pemahaman tentang suatu hal kepada peserta didik. Tujuan utama dari layanan informasi adalah diperolehnya pemahaman baru dari peserta didik akan berbagai hal, sepri akademik, pribadi, sosial, dan karir.

Tohirin (2009) mengungkapkan bahwa dalam layanan informasi memiliki beberapa teknik, yaitu; a. Ceramah, Tanya jawab, dan diskusi. Teknik ini paling umum digunakan dalam penyampaian informasi dalam berbagi kegiatan bimbingan dan konseling.

b. Melalui media. Menyampaian informasi dapat melaluai media tertentu sepetri alat peraga, media tulis, media gambar, poster, dan media elektronik seperti redio, tape, recorder, film, televisi, internet, dan lain-lain.

c. Acara khusus. Layanan informasi melalui cara ini dilakuakan berkenaan dengan acara khusus di sekolah atau madrasah; misalnya "Hari Tanpa Asap Rokok", "Hari Kebersihan Lingkungan Hidup", dan lain sebagainnya.

d. Narasumber. Layanan informasi juga dapat diberikan kepada peserta layanan dengan menggunakan nara sumber (manusia sumber)

Pada dasarnya berbagai metode dalam pelaksanaan layanan informasi dapat dilakukan inovasi dengan memanfaatkan media. Tujuannya agar motivasi siswa mengikuti layanan informasi lebih tinggi, dan daya pemahaman terhadap materi layanan menjadi lebih baik. Penyampaian layanan informasi untuk memudahkan siswa memahami meteri 
perlu ditempuh strategi layanan yang baik dan yang menarik sehingga siswa aktif mengikuti kegiatan layanan. Film bisa digunakan sebagi media dalam layanan informasi yang dapat memudahkan siswa untuk menerima isi dari layanan yang disampaikan guru pembimbing. Materi yang diberikan harus disesuaikan dengan kebutuhan siswa yaitu: membangun keyakinan diri, sifat optimis, mampu menilai secara obyektif, tanggung jawab, dan mampu berfikir rasional maupun realistis.

Menurut Susilana dkk (2009) mengemukakan"film disebut juga gambar hidup (motion pictures), yaitu serangkaian gambar diam (Istill pictures) yang meluncur secara cepat dan diproyeksikan sehingga menimbilkan kesan hidup dan bergerak". Film merupakan media yang menyampaikan pesan audiovisual dan gerak. Oleh karena itu film memberikan kesan yang impresif bagi pemirsanya. Lain halnya Yuliawan (2006) bahwa "film adalah benda yang tipis seperti kertas terbuat dari seluloid untuk merekam gambar negative melalui kaca kamera".

Berdasarkan permasalahan yang ditemukan, maka perlu dilakukan eksperimen berupa pemberian layanan informasi menggunakan media flm untuk meningkatkan kepercayaan diri peserta didik. Tujuan yang diharapkan dalam adalah untuk mengetahui pengaruh layanan informasi menggunakan media film terhadap kepercayaan diri siswa kelas VIII SMP Negeri 8 Metro.

\section{METODE PENELITIAN}

Desain penelitian yang digunakan adalah eksperimen. Rancangan penelitian menggunakan one group pretest-posttest design. Penelitian ini dilakukan di SMP Negeri 8 Metro. Rancangan penelitian seperti dibawah ini:

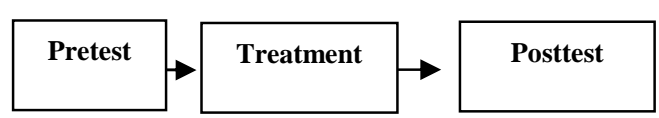

Gambar 1. Desain Penelitian

Populasi dalam penelitian ini adalah kelas VIII yang keseluruhannya terdiri dari 155 siswa. Sedangkan untuk sampel yaitu 
Sampel adalah siswa kelas $\mathrm{VIII}_{\mathrm{E}}$ berjumlah 30 siswa yang diambil menggunakan teknik sampling purposive sampling atau mengambil sampel berdasarkan pertimbangan tertentu. Berikut jumlah populasi penelitian:

\section{Tabel 1. Sebaran Anggota Populasi}

\begin{tabular}{|c|c|c|}
\hline No. & Kelas & Jumlah Siswa \\
\hline 1 & VIII $_{\mathrm{A}}$ & 32 \\
\hline 2 & VIII $_{\mathrm{B}}$ & 29 \\
\hline 3 & VIII $_{\mathrm{C}}$ & 32 \\
\hline 4 & VIII $_{\mathrm{D}}$ & 32 \\
\hline 5 & VIII $_{\mathrm{E}}$ & 30 \\
\hline \multicolumn{2}{|c|}{ Jumlah $^{\text {Siswa }}$} & 155 \\
\hline \multicolumn{2}{|l|}{ Sumber data: Dokumentasi TU SMP Negeri 8 } \\
\hline
\end{tabular}
Metro2013

Kegiatan pengumpulan data menggunakan angket kepercayaan diri. Sebelum dilakukan uji coba, angket ditimbang oleh ahli. Angket yang ditimbang oleh 3 ahli yaitu: Eko Susanto, M. Pd, Kons, Satrio Budi W. M. A, Agus Wibowo, M. Pd, dari Progam Studi Bimbingan dan Konseling, Fakultas Keguruan dan Ilmu Pendidikan (FKIP) Universitas Muhammadiyah Metro. Setelah itu, barulah diklasifikasikan ke dalam dua kategori memadai dan tidak memadai dan untuk menganalisis data yang telah terkumpul digunakan uji t:

$$
t_{\text {hitung }}=\frac{M d}{\sqrt{\frac{\sum x^{2} d}{N(N-1)}}}
$$

\section{HASIL DAN PEMBAHASAN}

Hasil analisis data menunjukkan bahawa terdapat pengaruh yang signifikan layanan informasi menggunakan media film terhadap percaya diri siswa. Dengan menggunakan taraf signifikasi $(\alpha)$ sebesar 0,05, diketahui bahwa perhitungan $\mathrm{t}_{\text {hitung }}=6,036>\mathrm{t}_{\text {tabel }}=$ 1,699), dengan demikian hipotesis yang menyatakan tidak ada pengaruh layanan informasi menggunakan media film terhadap kepercayaan diri siswa ditolak. Sehingga dinyatakan bahwa layanan informasi menggunakan media film berpengaruh terhadap kepercayaan diri siswa.

Hasil penelitian menunjukkan bahwa informasi yang diberikan pada layanan informasi menggunakan media film mampu memberikan pemahaman baru bagi peserta didik untuk merubah perilaku dan rasa minder menjadi memiliki rasa percaya diri. Meningkatnya kepercayaan diri peserta didik, sesuai 
dengan tujuan yang diharapkan dari pelaksanaan layanan informasi, yaitu diperolehnya pemahaman baru dari peserta didik. Hal tersebut seperti pendapat yang diungkapkan Tohirin (2009) bahwa:

Layanan informasi bertujuan untuk pengembangan kemandirian. Pemahaman dan penguasaan individu terhadap informasi yang diperlukan akan memungkinkan individu: (a) Mampu memahami dan menerima diri dan lingkungan secara objektif, positif dan dinamais, (b) Mengambil keputusan, (c) Mengarahkan diri untuk kegiata-kegiatan yang berguna sesuai dengan keputusan yang diambil, dan (d) Mengaktualisasikan secata terintegrasi.

Sejalan dengan Arsyad (2011) "Pelaksanaan layanan menggunakan media film dapat melengkapi pengalaman-pengalaman dasar dari siswa ketika mereka membaca, berdiskusi, selain itu juga mendorong dan meningkatkan motivasi, film menanamkan sikap dan segi efektif lainnya pada diri siswa". Ini berarti ada hubungan yang nyata penggunaan layanan informasi menggunakan media film terhadap percaya diri siswa yang rendah.
Pelaksanaan layanan informasi dengan menggunakan media film memiliki pengaruh positif terhadap percaya diri siswa sehingga sehingga timbulah sikap yang lebih baik. Melalui sebuah tayangan film siswa dapat tersentuh secara fisik maupun psikis. Dimana siswa lebih tertarik dengan sajian materi layanan dengan menggunakan media film. Dengan ketertarikan adanya media yang digunakan pada pelaksanaan layanan maka dapat memberikan motivasi siswauntuk lebih percaya diri dengan harapan siswa lebih menampilkan kemampuan dan optimis dalam diri siswa. Sejalan dengan Sadirman (2009) bahwa melalui media film dapat menyajikan praktik maupun teori dari yang bersifat umum sampai kekhusus, memikat perhatian siswa, selain itu juga dapat merangsang atau memotivasi kegiatan siswa.

Adanya hasil positif layanan informasi menggunakan media film terhadap kepercayaan diri peserta didik, adalah diakibatkan siswa bukan hanya mendengarkan guru menyampaikan materi, namun secara khusus juga mereka melihat. Keuntungan penggunaan media film 
seperti yang diungkapkan oleh Arsyad (2011: 49) bahwa film memiliki kelebihan yaitu, sebagai berikut:

a. Film dapat melengkapi pengalaman-pengalaman dasar dari siswa ketika mereka membaca, berdiskusi, dan lainlain. Film merupakan pengganti alam sekitar dan bahkan dapat menunjukan objek secara normal tidak dapat di lihat seperti cara kerja jantung ketika berdenyut.

b. Film dapat menggambarkan suatu proses secara tepat yang dapat disaksikan secara berulang-ulang jika dipandang perlu.

c. Disamping mendorong dan meningkatkan motivasi, film menanamkan sikap dan segi efektif lainnya.

d. Film yang mengandung nilainilai positif dapat mengundang pemikiran dan pembahasan dalam kelompok siswa. Fim dapat menyajikan peristiwa yang berbahaya bila dilihat secara langsung seperti lahar gunung berapi atau prilaku binatang buas.

e. Film dapat ditunjukan kepada kelompok besar atau kecil, kelompok yang heterogen maupun yang perorangan.

f. Dengan kemampuan dan teknik pengambilan gambar frame demi frame, film yang dalam kecepatan normal memakan waktu satu minggu dapat ditampilkan dalam satu atau dua menit.
Dengan demikian, penggunaan media film merangsang adanya motivasi peserta didik untuk memperhatikan materi yang guru sampaikan.

\section{KESIMPULAN DAN SARAN}

a. Kesimpulan

Berdasarkan hasil analisis dan hasil temuan pada saat penelitian berlangsung yang dilakukan pada siswa SMP Negeri 8 Metro, dengan demikian dapat disimpulkan bahwa layanan informasi yang laksanakan menggunakan media film dapat berpengaruh positif terhadap kepercayaan diri khususnya siswa kelas VIII. Hal ini dapat ditunjukkan pada temuan hasil uji hipotesis yaitu melalui pemberian layanan informasi menggunakan media film maka berpengaruh positif terhadap kepercayaan diri siswa. Setelah diadakannya layanan informasi siswa yang kurang percaya diri menjadi lebih percaya diri. Keadaan tersebut terlihat pada saat siswa berdiskusi dan berusaha untuk menampilkan diri pada saat penyampaian hasil diskusi kelompok dimana siswa lebih aktif, mandiri dan berani untuk 
mempertanggung jawabkan hasil Diskusi kelompoknya.

\section{b. Saran}

Berdasarkan hasil dan pembahasan yang dilakukan, maka saran yang dapat diberikan, yaitu: 1) bagi siswa: siswa yang memiliki percaya diri rendah, alangkah baiknya berusaha terus meningkatkan kepercayaan diri dengan mengikuti layanan informasi atau layanan bimbingan dan konseling lainnya sehingga tercapailah kepercayaan diri yang memberikan dampak positif bagi dirinya sendiri, 2) Kepada para peneliti, hendaknya dapat melakukan penelitian mengenai masalah percaya diri dengan kondisi subyek yang berbeda, namun menggunakan layanan, pendekatan, dan teknik yang sama tetapi dengan masalah yang berbeda dalam melaksanakan penelitian berikutnya. 3) Kepada guru bimbingan konseling, agar lebih mengefektifkan lagi layanan informasi dengan memanfaatkan media film untuk lebih meningkatkan percaya diri siswa. Penyampaian materi layanan dengan menggunakan media yang menarik akan mempermudah siswa dalam memahami dan menerima suatu informasi yang disampaikan, 4) bagi kepala sekolah; untuk kelancaran dan keefektifan pada pelaksanaan layanan informasi terhadap kepercayaan diri maka pihak sekolah untuk bisa lebih melengkapi sarana dan prasarana.

\section{DAFTAR PUSTAKA}

Arsyad, Azhar.2011. Media pembelajaran. Jakarta: PT. Raja Grafindo Persada

Lauster. 2013. percaya-diri-dalampsikologi (http://www.masbow.com. Diakses 23 Mei 2013 Pukul 04:15)

Prayitno. 2004.Seri Layanan Konseling L.1-L.9. Padang: Universitas Negeri Padang

Sadirman, Arief S. 2009. Media Pendidikan: pengertian, pengembangan, dan pemanfaatannya. Jakarta: PT. Raja Grafindo Persada

Santrok, John W. 2003. Adolescence Perkembangan Remaja Edisi Keenam. Jakarta: Erlangga

Susilana, Rudi dan Riyana, Cepi. 2009. Hakikat Media Pembelajaran, Pengembangan, Pemanfaatan, dan Penilaian. Bandung: CV. Wacana Prima. 
Tohirin. 2009. Bimbingan dan

Konseling Di Sekolah dan Madrasah (berbasis Integrasi). Jakarta: Rajawali Press

Zainal Aqib. 2012. Bimbingan dan Konseling Di sekolah. Jakarta: Rajawali Press

Yuliawan. 2006. Pemanfaatan Teknologi dalam Pembelajaran. Jakarta: Bina Cipta Press 